\title{
ROLE OF POTASSIUM IN THE LIPOLYTIC HORMONE EFFECT IN RAT ADIPOSE TISSUES
}

\author{
Keiichi Yoshimura, Tsutomu Hiroshige And Shinji ITOH \\ Department of Physiology, Hokkaido University \\ School of Medicine, Sapporo
}

The importance of electrolytes for the manifestation of the hormonal effect on various tissues was repeatedly emphasized ${ }^{1,2,3)}$. As to the influence of potassium ions on the action of lipolytic hormone, Mosinger and KUJALOVA $^{4)}$ first showed that the lipolytic action of catecholamine was significantly reduced in a potassium free medium, thus demonstrating the necessity of potassium for the effective lipolytic action of epinephrine. Since this effect of potassium was markedly reduced by the presence of ouabain, they suggested that epinephrine effect on adipose tissue might be linked with the potassium and/or sodium transporting pump. This view was supported by similar findings by other investigators ${ }^{5,6)}$.

Since these investigations were mainly concerned with the influence of potassium on hormonal effect in white adipose tissue, we examined in the present experiment a possible role of potassium in the lipolytic hormone effect in brown adipose tissue as well as white one of the rat. Data obtained are suggestive of the similarity of mechanisms involved in the hormoneactivated lipolysis in both tissues. On the basis of the findings, possible nature of the mechanism involved is briefly discussed.

\section{MATERIALS AND METHODS}

Animals used were male Wistar rats, weighing 250 to $350 \mathrm{~g}$, in their fed state. Conditions of the animals and procedures for preparation and incubation of adipose tissue were described in details previously ${ }^{7)}$. In brief, interscapular brown adipose tissue slices ( 30 to $50 \mathrm{mg}$ in weight) were incubated at $37.5^{\circ} \mathrm{C}$ for 2 hours in $2 \mathrm{ml}$ of Krebs-Ringer phosphate buffer ( $\mathrm{pH} 7.4$ ) in Warburg vessels under pure oxygen. Epididymal white adipose tissue ( 80 to $120 \mathrm{mg}$ ) was incubated in the same medium under air, using a metabolic shaker.

In some experiments in which potassium concentration was raised, sodium chloride was replaced with potassium chloride equimolarly. In the case of potassium free medium, $\mathrm{pH}$ was adjusted to 7.4 by adding sodium phosphate buffer. Free fatty acid (FFA) in the medium was determined by the colorimetric method of Duncombe ${ }^{8)}$ and

Received for publication July 30, 1969

吉村啓一, 広重 力, 伊藤真次 
glycerol by the method of KORN ${ }^{8)}$. Reagents used were theophylline (Wako Chem. Co.), norepinephrine (Sankyo Co.) and ouabain (Daiichi Chem. Co.).

\section{RESULTS}

1. Effect of ouabain and potassium free medium on hormone-stimulated lipolysis in epididymal white adipose tissue. FIG. 1 shows that the release of free

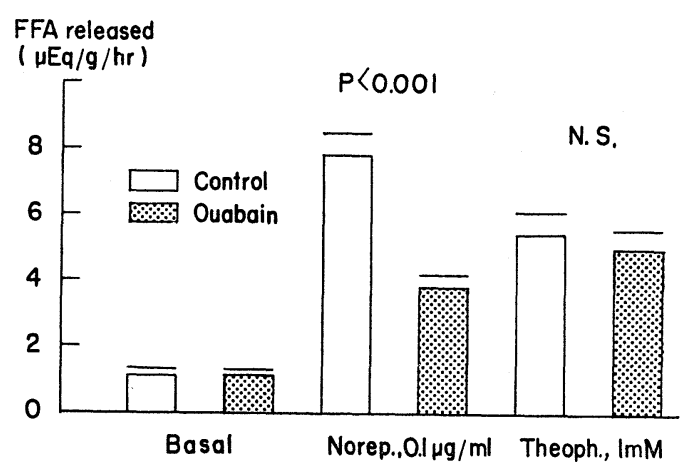

FIG. 1. Effect of ouabain on lipolysis induced by norepinephrine or theophylline in epididymal white adipose tissue in vitro. Doses of reagents were $0.1 \mu \mathrm{g} / \mathrm{ml}$ for norepinephrine, $1 \mathrm{mM}$ for theophylline and $5 \times 10^{-4} \mathrm{M}$ for ouabain. Mean values of seven paired determinations are accompanied by standard errors.

fatty acid (FFA) from epididymal adipose tissue was markedly stimulated by the addition of norepinephrine $(0.1 \mu \mathrm{g} / \mathrm{ml})$ and that this effect was inhibited, though not completely, by ouabain $\left(5 \times 10^{-4} \mathrm{M}\right)$. The inhibitory action of ouabain was less effective as the catecholamine concentration increased, as shown in TABLE 1. Similar pattern of inhibition was observed with the effect of

\section{TABLE 1.}

Inhibition by ouabain of FFA release from epididymal white adipose tissue in vitro. The amounts of $\mathrm{FFA}$ released are given in $\mu \mathrm{Eq} / \mathrm{g} / \mathrm{hr}$. All values are means \pm standard errors of four paired determinations. Ouabain was added in a final concentration of $5 \times 10^{-4} \mathrm{M}$. P shows the level of statistical significance of the difference between two values of paired determination.

\begin{tabular}{l|c|c|c|c}
\hline & Control & Ouabain & $\begin{array}{c}\text { Inhibition } \\
(\%)\end{array}$ & $\mathrm{P}$ \\
\hline $\begin{array}{c}\text { Basal } \\
\begin{array}{c}\text { Norepinephrine } \\
(\mu \mathrm{g} / \mathrm{ml})\end{array}\end{array}$ & $1.08 \pm 0.19$ & $1.16 \pm 0.15$ & & $\mathrm{NS}$ \\
0.1 & $7.95 \pm 0.55$ & $3.68 \pm 0.42$ & 54.1 & $<0.001$ \\
1.0 & $10.76 \pm 0.77$ & $7.86 \pm 0.96$ & 27.5 & $<0.01$ \\
\hline
\end{tabular}


potassium free medium as seen in TABLE 2. On the other hand, neither lipolytic effect of theophylline $(1 \mathrm{mM})$ nor basal rate of lipolysis in the absence

TABLE 2.

Effect of potassium omission on lipolysis induced by norepinephrine or theophylline in epididymal white adipose tissue. The amounts of FFA released are given in $\mu \mathrm{Eq} / \mathrm{g} / \mathrm{hr}$. Values are means \pm standard errors of paired deter. minations. Control medium denotes Krebs-Ringer phosphate buffer.

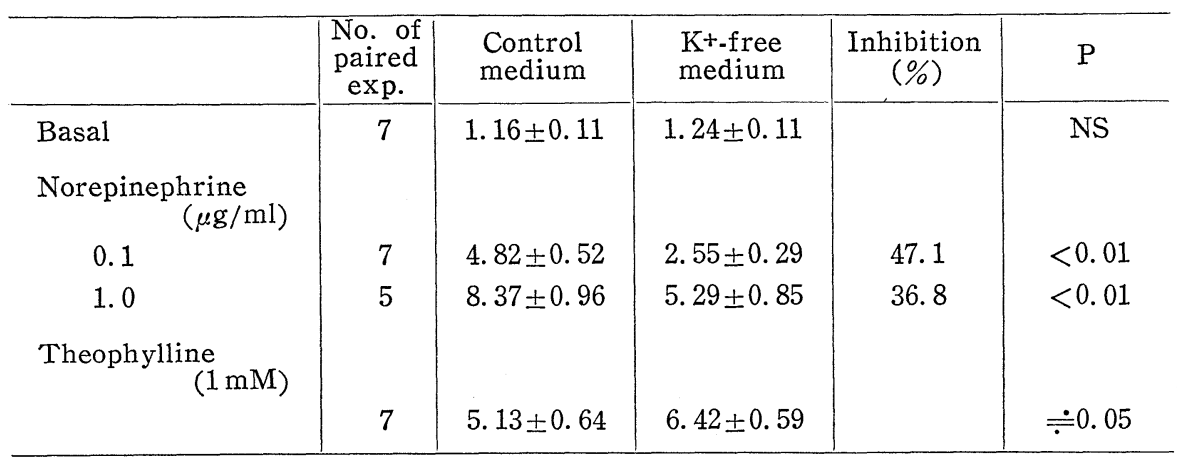

of added hormone was not influenced at all by the addition of ouabain (FIG. 1). In fact, lipolytic action of theophylline was rather increased in the absence of potassium ions in the medium (TABLE 2).

2. Effect of ouabain and potassium free medium on hormone-stimulated lipolysis and oxygen consumption in brown adipose tissue. Quite similar results were obtained with interscapular brown adipose tissue: the lipolytic effect of norepinephrine was significantly reduced by ouabain or the omission of potassium from the medium (FIG. 2, TABLE 3). Basal rate of lipolysis in brown adipose

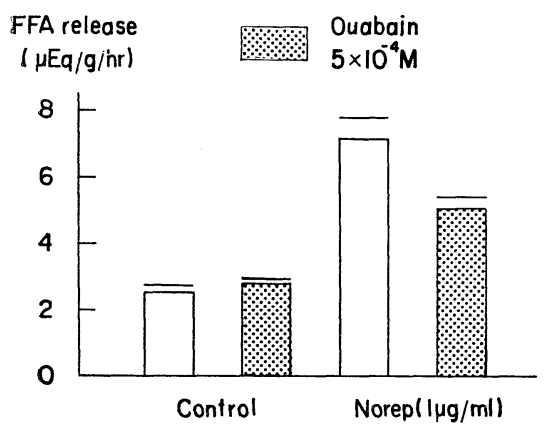

FIG. 2. Inhibition by ouabain of norepinephrine-induced lipolysis in interscapular brown adipose tissue. Average of six paired determinations.

tissue was again not influenced significantly by these conditions. The lipolytic effect of theophylline was increased by the omission of potassium from the medium (TABLE 3 ) as was with white adipose tissue. It should be noted that 
TABLE 3.

Effect of potassium free medium on glycerol release induced by norepinephrine or theophylline in interscapular brown adipose tissue. Control medium denotes Krebs-Ringer phosphate buffer. P shows the level of statistical significance of the difference between two values indicated by an arc.

\begin{tabular}{|c|c|c|c|c|}
\hline & Basal & $\begin{array}{l}\text { Norepinephrine } \\
\quad(1.0 \mu \mathrm{g} / \mathrm{ml})\end{array}$ & $\begin{array}{l}\text { Norepinephrine } \\
\text { effect }\end{array}$ & $\mathrm{P}$ \\
\hline \multicolumn{5}{|c|}{ Experiment I ( 9 paired determinations) } \\
\hline K-free medium & $1.32 \pm 0.09$ & 1. $68 \pm 0.11$ & $0.37 \pm 0.13$ & \multirow{2}{*}{$<0.005$} \\
\hline \multirow[t]{2}{*}{ Control medium } & $0.88 \pm 0.08$ & $3.29 \pm 0.50$ & $2.41 \pm 0.42$ & \\
\hline & Basal & $\begin{array}{l}\text { Theophylline } \\
\quad(1 \mathrm{mM})\end{array}$ & $\begin{array}{l}\text { Theophylline } \\
\text { effect }\end{array}$ & $\mathrm{P}$ \\
\hline \multicolumn{5}{|c|}{ Experiment II (4 paired determinations) } \\
\hline K-free medium & $0.93 \pm 0.23$ & $1.55 \pm 0.26$ & $0.62 \pm 0.03$ & \multirow{2}{*}{$<0.025$} \\
\hline Control medium & $0.87 \pm 0.26$ & $1.05 \pm 0.24$ & $0.18 \pm 0.05$ & \\
\hline
\end{tabular}

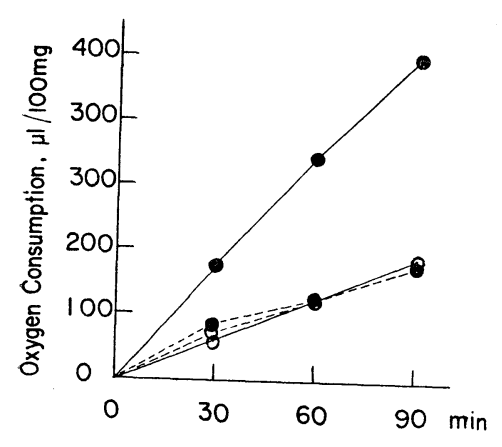

FIG. 3. Potassium dependency of hormonestimulated increase in respiration of brown adipose tissue. Open circles stand for control without added hormone, and solid ones for added norepinephrine $(1.0 \mu \mathrm{g} / \mathrm{ml})$. Solid line represents values in control medium (Krebs-Ringer phosphate buffer) and broken line those in $\mathrm{K}^{+}$-free medium. Note that a marked increment in respiration due to catecholamine stimulation was almost completely abolished in the absence of potassium. Average of nine paired determination.

the omission of potassium almost completely abolished the hormone-stimulated increase in the respiration as shown in FIG. 3. Similar inhibition of the hormone-induced increment in the respiration was also observed by the addition of ouabain (FIG. 4). In either case, basal rate of the oxygen consumption remained almost unaffected.

3. Interaction between ouabain and excess potassium on the hormone-induced lipolysis in epididymal white adipose tissue. Since norepinephrine-stimulated lipolysis was found in either adipose tissue to be ouabain-sensitive as well as potassium-dependent, interaction, if any, between ouabain and excess potassium in the lipolytic process was next examined. It was found that inhibitory effect of ouabain on the hormone-stimulated lipolysis was overcome 


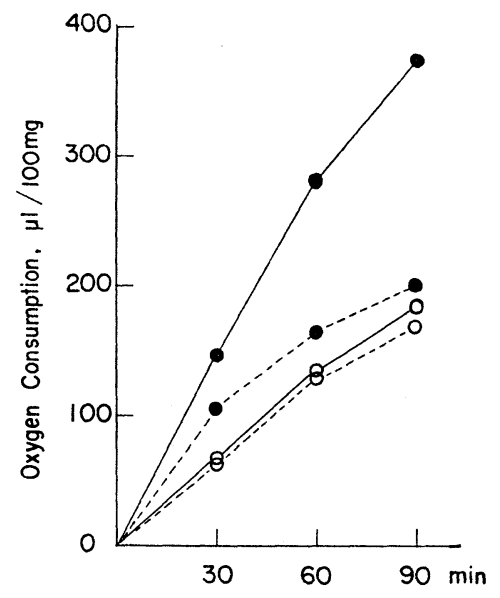

FIG. 4. Inhibition by ouabain of norepinephrine-stimulated respiration in brown adipose tissue. The same notations as in FIG. 3 except that broken line stands for ouabain addition ( 5 $\left.\times 10^{-4} \mathrm{M}\right)$. Average of six paired determinations.

by increasing the concentration of potassium in the incubation medium as shown in FIG. 5. In this series of experiment sodium chloride was replaced

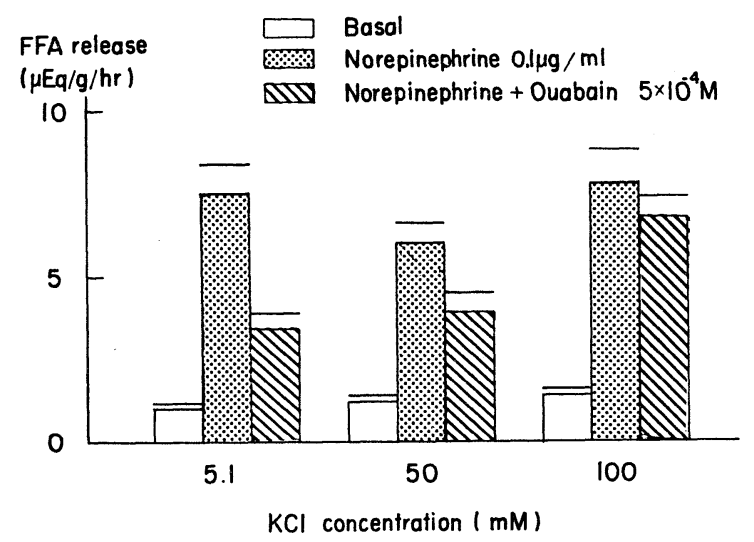

FIG. 5. Interaction between ouabain and excess potassium in the norepinephrine-induced lipolysis in white adipose tissue. Average of six to nine paired experiments. Note that neither basal rate nor catecholamine effect was affected by excess potassium, but ouabain inhibition became less effective at higher concentrations of potassium.

equimolarly by potassium chloride. It will be seen that excess potassium in the medium $(50 \mathrm{mM}$ and $100 \mathrm{mM}$ ) exhibited no influence on the basal as well as norepinephrine-stimulated lipolysis, whereas addition of excess of potassium markedly diminished the inhibitory effect of ouabain. Per cent inhibition by ouabain under varying concentration of potassium was plotted in FIG. 6 . It will be seen that at $5 \mathrm{mM}$ potassium chloride per cent inhibition by ouabain 


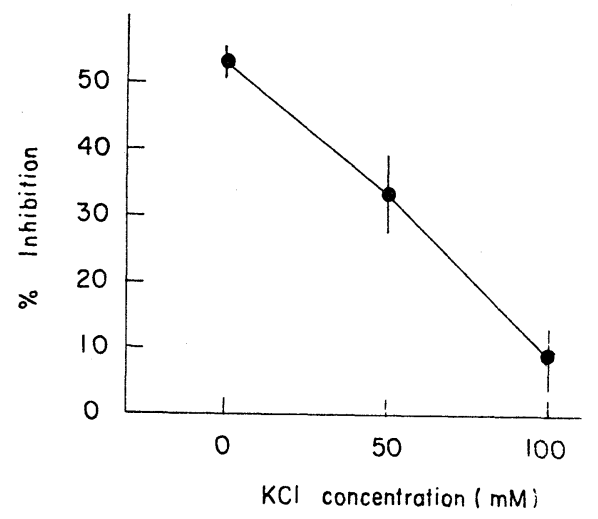

FIG. 6. Per cent inhibition due to ouabain of catecholamine effect in the presence of excess potassium. Per cent inhibition was calculated from data shown in FIG. 5. The dose of norepinephrine was $0.1 \mu \mathrm{g} / \mathrm{ml}$ and that of ouabain $5 \times 10^{-4} \mathrm{M}$.

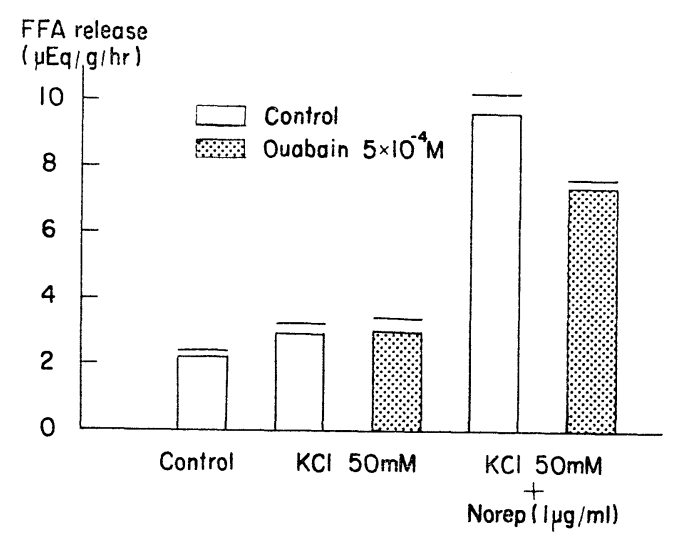

FIG. 7. Effect of ouabain on the hormone-induced lipolysis in brown adipose tissue in the presence of excess potassium. Six paired exp.

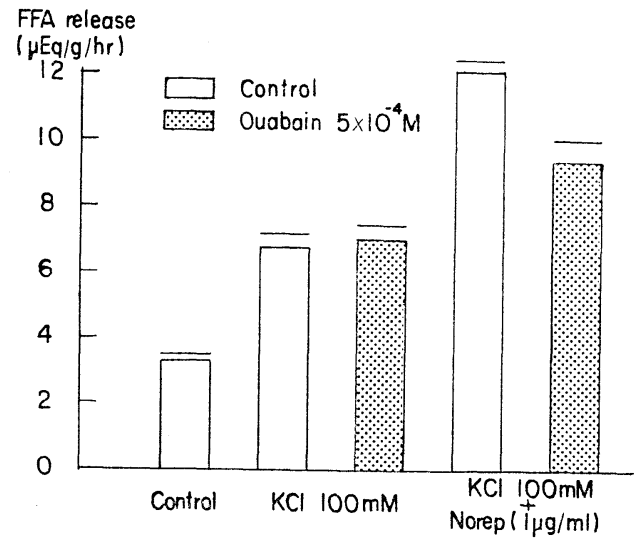

FIG. 8. Effect of ouabain on the excess $\mathrm{K}^{+}$-induced or hormonestimulated lipolysis in brown adipose tissue. Average of five paired experiments. 
was $54.5 \%$, at $50 \mathrm{mM}$ it reduced to $35.2 \%$, while at $100 \mathrm{mM}$ of potassium concentration it was only $9.8 \%$.

4. Effect of ouabain and excess potassium on the hormone-induced lipolysis in interscapular brown adipose tissue. Similar observation was repeated with brown adipose tissue. The results are shown in FIGS. 7 and 8 . It will be clear that FFA release increased markedly as the potassium concentration increased and this increment in FFA release was not affected by the addition of ouabain. Norepinephrine in an amount of $1.0 \mu \mathrm{g} / \mathrm{ml}$ markedly stimulated the FFA release even in the presence of excess potassium. This increment induced by catecholamine was significantly suppressed by the simultaneous addition of ouabain. The magnitude of inhibition by ouabain however remained essentially similar in spite of different concentrations of excess potassium in the medium.

\section{DISCUSSION}

Although much attention has been paid to the importance of electrolytes for the manifestation of hormonal effect on white adipose tissue ${ }^{10)}$, few attempts have been made to find out the role of ions in the hormone action on brown adipose tissue. REED and $\mathrm{FAIN}^{11)}$ appear the first who examined this problem. They reported, using rat brown fat cells, that the omission of potassium from the incubation medium blocked the large increases in respiration seen after the addition of lipolytic agents such as theophylline or epinephrine. Furthermore, they showed that the epinephrine-induced increase in lipolysis was drastically, though not completely, reduced in the absence of potassium. In the present experiment using brown adipose tissue slices, we have amply confirmed these observations on the respiration (FIG. 3) and lipolysis (TABLE 3). In addition, we have shown that the hormone-induced increment of lipolysis was also suppressed by ouabain (FIG. 2). Thus, all these observations are quite analogous to those obtained with white adipose tissue (TABLES 1 and 2, FIG. 1), that is, the catecholamine-induced stimulation of lipolysis in both tissues is reduced by ouabain or potassium omission. It is thus surmised that similar mechanisms are involved in the hormoneinduced lipolysis in both adipose tissues.

The findings that lipolytic effect of norepinephrine is well inhibited by ouabain and also requires potassium ions would suggest a possible involvement of active transport system for electrolytes, since the active process is known in various tissue preparations to be inhibited by the presence of ouabain or the omission of potassium from the medium ${ }^{12)}$. Up to the present time, a body of evidence has been accumulated indicating that specific $\mathrm{Na}-\mathrm{K}$ dependent ATPase participates in the actively linked transport of these 
cations. In fact, evidence is recently obtained for the presence of a Na-K dependent ATPase, though in an extremely small fraction, in epididymal adipose tissue ${ }^{13)}$. It is known that the inhibition of ATPase activity by cardiac glycosides is prevented by increasing the potassium concentration in the incubation medium ${ }^{14)}$. Thus, interaction observed between ouabain and excess potassium in the expression of hormone-induced lipolysis (FIG. 6) may be taken as a further support for participation of the ATPase in the enhanced lipolysis under the influence of catecholamine. Nevertheless, the findings with brown adipose tissue that marked stimulation of lipolysis by excess potassium was not affected at all by ouabain and that no apparent interaction was seen between them in the manifestation of hormone-induced lipolysis (FIGS. 7 and 8) might be incompatible with the above interpretation.

It is of special interest to note here that the lipolytic action of theophylline was not suppressed at all by ouabain and rather increased in the absence of potassium ions. Similar potentiation of the theophylline effect by the omission of potassium ions was reported by $\mathrm{FAIN}^{6,10)}$ in the experiments using isolated white fat cells, but REED and FAIN ${ }^{11)}$ could not demonstrate this in isolated brown fat cells. FAIN ${ }^{6)}$ also reported that ouabain caused a similar stimulation of lipolytic effect of theophylline. Our results however failed to confirm this (FIG. 1). These discrepancies, though minor, may be attributable to the difference in sensitivity to ouabain between adipose tissue slices and isolated fat cells. Since theophylline is known to activate lipolysis by inhibiting the activity of phosphodiesterase which catalyzes the breakdown of cyclic $3^{\prime}, 5^{\prime}$-AMP, potentiation of the theophyline effect by the omission of potassium may be due to an enhancement of lipase activation by cyclic AMP. In fact, MosInger and VAUGHAN ${ }^{15)}$ reported that lipolytic action of cyclic AMP was enhanced by the omission of potassium ions from the phosphate buffer medium. They stressed variable responses of adipose tissue to this nucleotide depending on animal conditions and also ionic composition of incubation medium. In spite of this complexity, it may be surmised that the enhanced lipolysis by theophylline might be mediated through stimulation of cyclic AMP formation.

Comparison of the lipolytic action between catecholamine and theophylline revealed some interesting contrast. As was repeatedly shown ${ }^{16,17)}$, both agents are similarly lipolytic and also synergistic. And yet, difference in their mode of action is apparently marked as shown in the present experiment. Norepinephrine effect was clearly ouabain-sensitive and potassium dependent, whereas reverse is true with the theophylline effect. In a previous report $^{18)}$, we suggested that enhanced lipolysis induced by excess potassium could also involve an enhanced production of cyclic AMP in brown adipose tissue. The fact that excess potassium-induced lipolysis was not affected at all by ouabain (FIGS. 7 and 8 ) may support this suggestion. On the 
basis of these findings, it is easily assumed, as was first suggested by Mosinger and VAUGHAN ${ }^{19}$, that there may be two mechanisms involved in the enhanced lipolysis in adipose tissues; one of them linked somehow to a $\mathrm{Na}-\mathrm{K}$ dependent ATPase, the other related to the production of cyclic AMP. Since potassium exhibited influence on either of them, i.e., the omission of potassium was inhibitory in the former while rather stimulatory in the latter, it may be surmised that potassium ions play some essential role in the operation of these two mechanisms. Although Na-K dependent ATPase and adenyl cyclase are believed to be localized in cell membranes, their anatomical relation as well as functional similarity and dissimilarity are to be elucidated. In this connection, it is noteworthy that Ho et $a .^{5)}$ reported an inhibition of adenyl cyclase activity of adipose tissue homogenate by prior incubation of adipose tissue in a potassium free medium or ouabain-containing medium. Although their results appear to fail to explain the stimulation of theophylline effect in the potassium free medium, they may offer a possible explanation for both catecholamine-stimulated and theophylline- or excess potassiuminduced lipolysis solely by the increased production of cyclic AMP. Evidently, more investigations are needed to elucidate this problem.

\section{SUMMARY}

1. The influence of potassium ions upon the lipolytic hormone effect in vitro was examined on epididymal white as well as interscapular brown adipose tissue slices.

2. In either adipose tissue, the omission of potassium from incubation medium markedly, though not completely, diminished the catecholamine effect on lipolysis.

3. Similar inhibition was obtained by the addition of ouabain. This inhibitory effect of ouabain was well overcome in white adipose tissue by increasing the potassium concentration in the medium, whereas in brown adipose tissue no interaction between ouabain and potassium was observed.

4. Lipolytic action of theophylline was not affected at all by ouabain in both adipose tissues and was significantly increased in the absence of potassium in the medium.

5. Catecholamine-stimulated increase in the respiration of brown adipose tissue was almost completely abolished by ouabain or potassium omission.

6. It is suggested that two mechanisms may be involved in the enhanced lipolysis. It is possible that potassium ions play some essential role in the operation of these mechanims. 


\section{REFERENCES}

1) Zor, U., Lowe, I.P., Bloom, G. And Field, J.B.: The role calcium in TSH and dibutyryl $3^{\prime}, 5^{\prime}$ cyclic AMP stimulation of thyroid glucose oxidation and phospholipid synthesis. Biochem. Biophys. Res. Comm. 33: 649, 1968.

2) Vale, W. And Guillemin, R.: Potassium-induced stimulation of thyrotropin release in vitro. Requirement for presence of calcium and inhibition by thyroxine. Experientia 23 : 855, 1968.

3) Schramm, M.: Amylase secretion in rat parotid slices by apparent activation of endogenous catecholamine. Biochim. Biophys. Acta 165: 546, 1968.

4) Mosinger, B. And Kujalova, V.: Potassium-dependent lipomobilizing effect of adrenaline on incubated adipose tissue. Biochim. Biophys. Acta 116:174, 1966.

5) Ho, R. J., Jeanrenaud, B., Posternak, Th., and Renold, A. E.: Insulin-like action of ouabain. II. Primary antilipolytic effect through inhibitition of adenyl cyclase. Biochim. Biophys. Acta 144: 74, 1967.

6) FAIN, J.N.: Effect of $\mathrm{K}^{+}$, valinomycin, tetraphenylborate and ouabain on lipolysis by white fat cells. Mol. Pharmacol. $4: 349,1968$.

7) Yoshimura, K., Hiroshige, T. AND ITOH, S.: Lipolytic action of serotonin in brown adipose tissue in vitro. Japan. J. Physiol. 19: 176, 1969.

8) Duncombe, W.G.: The colorimetric micro-determination of long chain fatty acids. Biochem. J. $88: 7,1963$.

9) KORN, E. D.: Clearing factor, heparin-activated lipase. Isolation and characterization of the enzyme from normal rat. J. Biol. Chem. 215: 1, 1955.

10) FAIN, J.N.: Stimulation by insulin and prostaglandin $E_{1}$ of glucose metabolism and inhibition of lipolytic action of theophylline on fat cells in the absence of potassium. Endocrinology 83 : 548, 1968.

11) ReEd, N. AND FAIN, J.N.: Potassium-dependent stimulation of respiration in brown fat cells by fatty acids and lipolytic agents. J. Biol. Chem. 243: 6077, 1968.

12) Skou, J.C.: Enzymatic basis for active transport of $\mathrm{Na}$ and $\mathrm{K}$ across cell membrane. Physiol. Rev. 45: 596, 1965.

13) Modolell, J.B. And Moore, R. O.: ATPase activities of rat epididymal adipose tissue. Biochim. Biophys. Acta 135: 319, 1967.

14) Dunham, E.T. And GLynn, I.M.: Adenosinetriphosphatase activity and the active movements of alkali metal ions. J. Physiol. 156:274, 1961.

15) Mosinger, B. And Vaughan, M.: The action of cyclic $3^{\prime}, 5^{\prime}$-adenosine monophosphate on lipolysis in rat adipose tissue. Biochim. Biophys. Acta 144:569, 1967.

16) Robison, G. A., Butcher, R.W. and Sutherland, E. W.: Cyclic AMP. Ann. Rev. Biochem. 37: 149, 1968.

17) Ikemoto, H., Hiroshige, T. AND Itoh, S.: On possible mechanisms in an increased thermogenesis in adipose tissues of the rat. Japan. J. Physiol. 19:293, 1969.

18) Yoshimura, K., Hiroshige, T. AND Itoh, S.: Stimulation of respiration and lipolysis in rat brown adipose tissue by excess potassium. J. Biochem. (Tokyo) 66 : 565, 1969.

19) Mosinger, B. And Vaughan, M.: Effects of electrolytes on epinephrine stimulated lipolysis in adipose tissue in vitro. Biochim. Biophys. Acta 144:556, 1967. 